\title{
AN ANALYSIS OF THE COMMUNITY COMPOSITION OF THE XIPHOPHORA GLADIATA DOMINATED SUBZONE OF THE TASMANIAN SUBLITTORAL FRINGE
}

\author{
by E. L. Rice
}

(with five tables and nine text-figures)

RICE, E.L., 1989 (31:x): An analysis of the community composition of the Xiphophora gladiata dominated subzone of the Tasmanian sublittoral fringe. Pap. Proc. R. Soc. Tasm. 123: 191-209. https://doi.org/10.26749/rstpp.123.191 ISSN 0080-4703. Biological Sciences Branch, Department of Fisheries and Oceans, Halifax Research Laboratory, PO Box 550, Halifax, Nova Scotia B3J 2S7, Canada; formerly Department of Botany, University of Tasmania

The rocky shore sublittoral fringe of the oceanic coasts of Tasmania contains a subzone dominated by the large brown alga Xiphophora gladiata. The community composition of this subzone is here examined at fourteen sites. The phytal and faunal assemblages are analysed by principal co-ordinate, classification and nodal analyses. This subzone is found to have a high species richness, including species which had been thought to occupy only higher or lower tidal levels. It is suggested that both plant and animal assemblages are strongly influenced by wave exposure, freshwater run-off and geography.

Key Words: marine community composition, sublittoral fringe, Xiphophora, multivariate analyses.

\section{INTRODUCTION}

The rocky shores of southeastern Australia are known to be occupied primarily by barnacles and molluscs in the upper intertidal (Underwood 1981), while algae dominate at midshore level and below. In particular, the sublittoral fringe zone characteristically has a canopy of various species of large brown algae, many of which are restricted to this zone, with often two or three understorey species below the canopy (Womersley 1981). The algal and animal communities of this fringe on Tasmanian rocky shores are not well known. Intertidal studies (Guiler 1952a,b, 1954, Guiler et al. 1958, Bennett \& Pope 1960, King 1973, Saenger 1974) generally make little detailed reference to this level, beyond mentioning indicator species. The few subtidal studies (Cribb 1954, Edgar 1983a,b, 1984) have mainly been concerned with greater depths and were restricted to a few specific locations.

In very exposed, rocky areas on the oceanic coasts of Tasmania, this sublittoral fringe is dominated by the alga Durvillaea potatorum (Bennett \& Pope 1960, Edgar 1984). With increasing levels of shelter, Durvillaea is replaced by Xiphophora gladiata, Lessonia corrugata, Phyllospora comosa and other algae (Edgar 1984). On shores where Xiphophora is not itself the dominant sublittoral fringe species, it often occurs in a thin band just above the dominant species
(Bennett \& Pope 1960). Thus, on the oceanic coasts of Tasmania it is possible to define a Xiphophora subzone, dominated by $X$. gladiata, which marks the highest limit of the sublittoral fringe on very exposed shores and represents the upper sublittoral zone on moderately exposed ones. This paper is a description of the assemblage of species in this subzone.

\section{MATERIALS AND METHODS}

The geographic range of Xiphophora gladiata ssp. gladiata (sensu Rice Kenchington 1987, Rice 1989), and hence of the subzone, is restricted to the oceanic east, south and west coasts of Tasmania. Samples were collected at fourteen sites distributed throughout this area and the sites grouped into several geographic regions to facilitate the interpretation and discussion of results (table 1). The D'Entrecasteaux Channel and Southwest regions are distinctive in that they are heavily influenced by the tannin-rich run-off of the Huon River and the Old and Spring Rivers respectively. The other sites were mainly on exposed, open coasts.

At each site, two $0.25 \mathrm{~m}^{2}$ grids were randomly placed within a distance of $10 \mathrm{~m}$ of each other in the Xiphophora subzone. These grid and sample sizes were predetermined by the requirements of a 
TABLE 1

Sampling Sites with Details of their Environment

\begin{tabular}{|c|c|c|c|c|}
\hline $\begin{array}{l}\text { Region/Geology } \\
\text { Site code/Site }\end{array}$ & Latitude & Longitude & $\begin{array}{c}\text { Exposure } \\
\text { index* }\end{array}$ & $\begin{array}{l}\text { Sampling } \\
\text { date }\end{array}$ \\
\hline \multicolumn{5}{|c|}{ Northwest/Precambrian orthoquartzite bedrock } \\
\hline (1) West Point & $40^{\circ} 56 \mathrm{~S}$ & $144^{\circ} 37^{\prime} \mathrm{E}$ & 26 & 16.11 .85 \\
\hline (2) North Mawson Bay & $40^{\circ} 56 ' \mathrm{~S}$ & $144^{\circ} 37^{\prime} \mathrm{E}$ & 27 & 17.11 .85 \\
\hline (3) Bluff Hill Point & $41^{\circ} 01^{\prime} \mathrm{S}$ & $144^{\circ} 37^{\prime} \mathrm{E}$ & 28 & 16.11 .85 \\
\hline \multicolumn{5}{|c|}{ West/Precambrian metaquartzite bedrock } \\
\hline (4) Cape Sorell & $42^{\circ} 12^{\prime} \mathrm{S}$ & $145^{\circ} 10^{\prime} \mathrm{E}$ & 14 & 3.11 .85 \\
\hline \multicolumn{5}{|c|}{ Southwest/Precambrian metaquartzite bedrock and boulders } \\
\hline (5) Bathurst Channel ${ }^{\dagger}$ & $43^{\circ} 20^{\prime} \mathrm{S}$ & $146^{\circ} 00^{\prime} \mathrm{E}$ & 01 & 27.02 .85 \\
\hline (6) Bramble Cove ${ }^{\dagger}$ & $43^{\circ} 19^{\prime} \mathrm{S}$ & $145^{\circ} 59^{\prime} \mathrm{E}$ & 02 & 25.02 .85 \\
\hline (7) Spain Bay ${ }^{\dagger}$ & $43^{\circ} 22^{\prime} \mathrm{S}$ & $145^{\circ} 58^{\prime} \mathrm{E}$ & 06 & 25.02 .85 \\
\hline
\end{tabular}

D'Entrecasteaux Channel/Jurassic dolerite boulders with a Permian limestone bedrock outcrop at White Cliff

\begin{tabular}{|c|c|c|c|c|}
\hline (8) Verona Sands ${ }^{\dagger}$ & $43^{\circ} 17^{\prime} \mathrm{S}$ & $147^{\circ} 09^{\prime} \mathrm{E}$ & 05 & 20.09 .85 \\
\hline (9) Ninepin Point ${ }^{\dagger}$ & $43^{\circ} 17^{\prime} \mathrm{S}$ & $147^{\circ} 10^{\prime} \mathrm{E}$ & 15 & 23.09 .84 \\
\hline (10) White Cliff ${ }^{\dagger}$ & $43^{\circ} 17^{\prime} \mathrm{S}$ & $147^{\circ} 11^{\prime} \mathrm{E}$ & 10 & 20.09 .85 \\
\hline
\end{tabular}

Southeast/Permian glaciomarine sandstone bedrock

$\begin{array}{lllll}\text { (11) Blowhole } & 43^{\circ} 02^{\prime} \mathrm{S} & 147^{\circ} 57^{\prime} \mathrm{E} & 12 & 20.09 .85 \\ \text { (Tasman Peninsula) } & & & \end{array}$

Northeast/Devonian granodiorite bedrock

\begin{tabular}{|c|c|c|c|c|}
\hline (12) Bums Bay & $41^{\circ} 17^{\prime} \mathrm{S}$ & $148^{\circ} 21^{\prime} \mathrm{E}$ & 07 & 26.09 .85 \\
\hline (13) Skeleton $\mathrm{Bay}^{\dagger}$ & $41^{\circ} 15^{\prime} \mathrm{S}$ & $148^{\circ} 19^{\prime} \mathrm{E}$ & 08 & 26.09 .85 \\
\hline (14) Gardens Shoal & $41^{\circ} 10^{\prime} \mathrm{S}$ & $148^{\circ} 17^{\prime} \mathrm{E}$ & 21 & 26.09 .85 \\
\hline
\end{tabular}

* By Baardseth's (1970) method.

${ }^{\dagger}$ Sampled with the aid of SCUBA.

study of geographic morphological variation in Xiphophora gladiata ssp. gladiata (Rice Kenchington 1987). The resulting survey design may have been less than ideal for the present ecological purposes. In particular, the small area sampled at each site $\left(0.5 \mathrm{~m}^{2}\right)$ may have led to the non-recording of rare species or those occurring in rare patches. At a few sites, however, the Xiphophora subzone is so narrow that the $0.5 \mathrm{~m}$ side of the grid could have projected both into the eulittoral and into Durvillaea-dominated parts of the sublittoral fringe. In practice, at two sites (Ninepin Point and White Cliff) the average number of species per $0.25 \mathrm{~m}^{2}$ grid was the same as that for $1 \mathrm{~m}^{2}$ grids (Rice Kenchington 1987), suggesting that any loss of rarities was minor.
Similarly, at the few sites sampled where the presence of Durvillaea reduced the Xiphophora subzone to a narrow fringe, care was taken to reject any random grid placement that would have extended beyond the subzone. Thus, the survey design was considered sufficient for present purposes.

All Xiphophora plants in each grid were harvested, by cutting with a sharp knife as close as possible to the substratum, and bagged. After the removal of Xiphophora, all other macroscopic benthos in the grids, including both algae and animals, were collected and separately bagged. At some sites this procedure was performed underwater by SCUBA diving (table 1). At others, sampling was conducted when the main bed of 
Xiphophora was exposed at low tide. All material was transported to the laboratory on ice in a large insulated container. On arrival, it was frozen and held at $-20^{\circ} \mathrm{C}$ until processed. Additional epifloral and epifaunal species, as well as unattached animals living among the Xiphophora fronds, were collected from these plants in the laboratory. The Xiphophora plants were carefully searched for epiphytes, as each plant was examined in detail for inclusion in a morphometric study of that species (Rice Kenchington 1987).

All plants and animals collected were identified to species level where possible, or else to the lowest possible taxon, using the available keys and guides (Hale 1927, 1929, Fritsch 1935, 1945, May \& Macpherson 1958, Dixon 1958, Macpherson \& Gabriel 1962, Cotton 1964, Womersley 1964, 1967, 1984, Saito \& Womersley 1974, Westcott 1976, Bold \& Wynne 1978, Ponder \& Creese 1980, Kaas \& van Belle 1980, Dartnall 1980, Fuhrer et al. 1981, Shepherd \& Thomas 1982, Marine Research Group of Victoria 1984, Phillips 1984, Johansen \& Womersley 1986). Assistance with identifications was provided by Miss A Green, Mrs L. Turner, Dr J. Phillips and Prof. H.B.S. Womersley. Representative collections of the invertebrate animals were deposited in the Tasmanian Museum and the Zoology Department, University of Tasmania collections. Herbarium sheets of the algae were lodged at the Tasmanian Herbarium (HO), located in the grounds of the University of Tasmania.

A wave exposure index was determined for each site using the cartographical method of Baardseth (1970). The value of this index is equal to the number of $9^{\circ}$ sectors, radiating from the site, which are open to the sea for $7.5 \mathrm{~km}$ or further.

\section{Data Reduction and Preparation}

For analysis, the data were recorded as presence or absence. Such binary data is less informative than abundances (Clifford \& Stephenson 1975), but this loss of information was considered preferable to introducing spurious "abundance" differences into the data. The data set was not reduced by the elimination of rare species. More than half of the species found were recorded at only one site and the elimination of these singletons, let alone species found at only two or three sites, would waste much of the information content of the data. The retention of these rare species, however, will have led to the inclusion of extra "noise" in the data set with any given survey effort, since their distributions cannot be recorded with the same precision as that of a common species. The singleton records did not usually represent the presence of a single individual in the collections, but rather many individuals from one place. Indeed, in many cases these species were recorded from both grids at their site of occurrence.

The records of amphipods and isopods required special treatment. These animals were mostly found amongst the bagged Xiphophora and, indeed, this is an established underwater collecting technique for such species (Edgar 1983a,b,c) However, where the $X$. gladiata was harvested while semi-exposed at low tide, only those species of amphipods and isopods which retreat among or clasp its fronds could be so collected. Following examination of the field data, it was concluded that only the large (c. $10 \mathrm{~mm}$ ) isopod Amphoroidea elegans was adequately sampled at all sites. It clings tenaciously to $X$. gladiata, while its size and bright orange colour make it easy to detect amidst the alga. All other isopods and all amphipods were eliminated from the analyses. No further data reduction was considered necessary.

The species lists for the two $0.25 \mathrm{~m}^{2}$ grids at each of the fourteen sites were combined for these analyses. However, the plant and animal data sets were analysed separately, as these two components of the community were expected to have different ecological response patterns.

\section{Analytical Methods}

From each data set, two similarity matrices were calculated, one for species ( $R$-mode) and one for sites (Q-mode), using the Dice (1945) coincidence index. The Dice index expresses the number of shared descriptors as a proportion of the richness of the objects being compared (cf. Faith et al. 1987). This coefficient is almost linear with ecological distance, until the number of shared species approaches zero (Dr P. Minchin, pers. comm.).

The sites and species were classified using an agglomerative, hierarchical ("SAHN": Sneath \& Sokal 1973), clustering algorithm with average linkage between groups ("UPGMA": Sneath \& Sokal 1973), using the CLUSTER subprogram of SPSS $^{\times}$(SPSS Inc. 1986).

The resulting classifications were compared using nodal analysis (Colvocoresses \& Musick 1984) in which the "constancy" and "fidelity" of each species group to each site group are compared. For this, each dendrogram is divided into a series of groups, defined at some arbitrarily chosen level of similarity. The "constancy" of a species group at 
a site group is then computed as the ratio of the number of occurrences of the species in the former group at the sites in the latter group to the total number of possible occurrences (the product of the number of species in one group and the number of sites in the other). From these "constancy" values, "fidelity" is calculated as the constancy of a species group at a site group divided by its average constancy over all site groups. "Constancy" ranges from zero (no occurrences) to unity (every species in the species group is ubiquitous throughout the site group). "Fidelity" has a value of one for site groups with average constancy (for a given species group) and is greater than one where the species group has above average occurrence at a site group.

The matrices of similarity (S) were transformed into matrices of distance (D) (Legendre \& Legendre 1983) by:

$$
\mathrm{D}=-0.5(1-\mathrm{S})^{2} .
$$

The sites and species were then ordinated by Principal Co-ordinates Analyses (Gower 1966) of these distance matrices, calculated by the PCORD macro of GENSTAT (Alvey et al. 1977). This technique allows a free choice of similarity coefficient (unlike Principal Components or Factor Analyses), while preserving undistorted the spatial relationships between the objects, and hence allows the advantages of the Dice index to be carried into the ordination (Clifford \& Stephenson 1975 Legendre \& Legendre 1983).

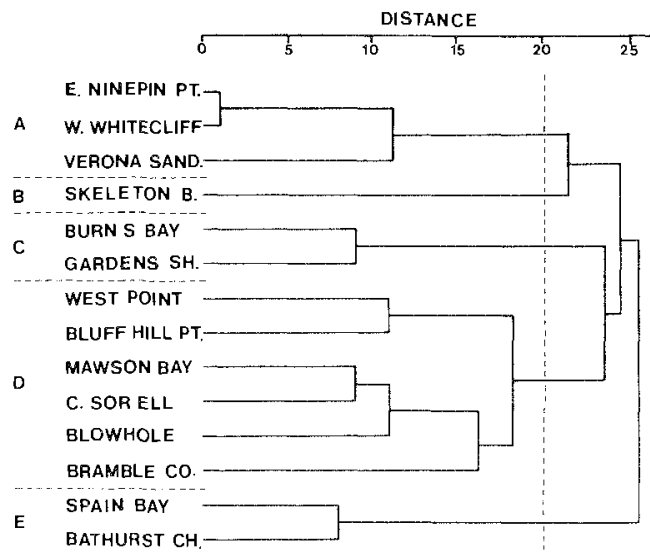

FIG. I - A dendrogram of the study sites classified by algal species occurrences at the sites. The broken line is the distance selected at which to examine site groupings.

\section{RESULTS AND DISCUSSION}

The plants and animals collected from the Xiphophora subzone are listed in tables 2 and 3 (pp. 202-205) respectively. These tables include species from all areas and show the occurrence of each species at each site. Species directly associated with $X$. gladiata, either as epiphytes or as free-living species collected from amongst the fronds of harvested plants, are indicated. Specimens of un-named or unidentified species have been deposited in the Tasmanian Museum or Herbarium. All further results and discussion are confined to data in these tables.

Five algal and six animal species each occurred at one-third or more of the sites: the upright red algae Laurencia elata, Ballia callitricha, Corallina officinalis; the large brown algae Cystophora xiphocarpa and $C$. subfarcinata; the prostrate sponge Callyspongia clathrata; the isopod Amphoroidea elegans; the limpet Patelloida victoriana; the large predatory whelk Thais textilosa; the mussel Mytilus edulis planulatus; and the epiphytic bryozoan Emma triangula. These 11 species, plus Xiphophora gladiata itself, therefore represent the "core" species of the Xiphophora subzone assemblage.

\section{Algae}

The dendrogram of sites based on algal species occurrence (fig. 1) shows that geographicallyadjacent sites tend to have similar algae. At the arbitrarily chosen similarity level drawn, the three D'Entrecasteaux Channel sites (Group A) cluster together, as do Burns Bay and Gardens Shoal (Group C: northeast Tasmania) and Spain Bay and Bathurst Channel (Group E: southwest Tasmania). However, the largest site group (Group D) contains all of the exposed west coast sites and the exposed Blowhole site, suggesting environmental rather than geographic control. All of the Group D sites, except Bramble Cove, are very exposed. Group C, containing the exposed northeast coast sites, clusters with Group D, thus reinforcing the conclusion that this dendrogram is jointly determined by the effects of exposure and geographic location.

These same data are displayed in figure 2 , with the stations ordinated on the first two principal coordinate axes of their distance matrix (jointly accounting for $45.6 \%$ of the variance). Figure 2 shows similar relationships to figure 1 . The four major geographic regions (defined a priori) are discrete in this "algal occurrence" hyperspace, even 


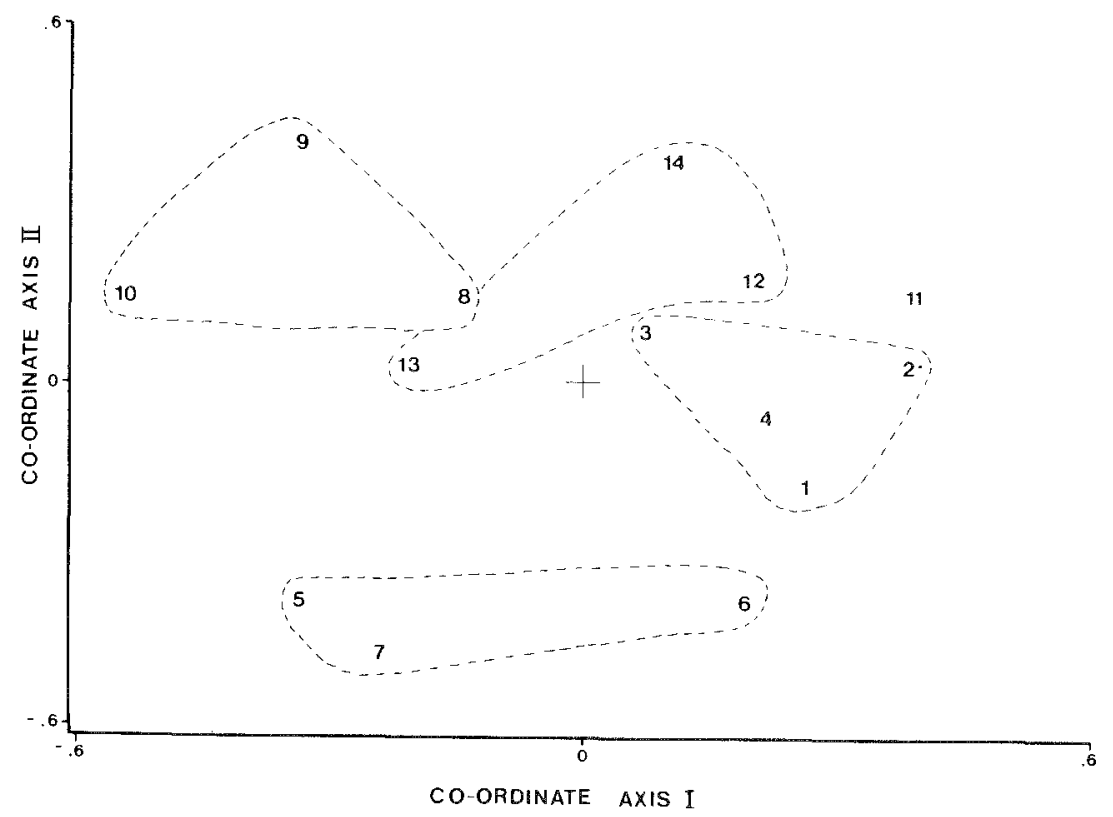

FIG. 2 - A plot of the study sites on the first two principal co-ordinate axes based on the distance matrix of algal occurrence. For site codes see table $I$.

when one site of a region lies close to those from another region. The first axis may be related to exposure, with the more exposed sites having higher scores, while the second tends to separate southwestern sites from the remainder. Those southwestern sites are influenced by the tannincoloured waters of Port Davey, which are known to reduce light penetration and to produce major biological effects (Edgar 1984). Taken together, these analyses indicate that the algal species composition of the Xiphophora subzone is influenced to some degree by exposure and geographic position, with perhaps a local effect of tannins near Port Davey.

In the dendrogram of algal species (fig. 3), nine clusters were recognised. Few of these can be explained biologically, given the poor state of present knowledge of the autecology of these species. The Group 1 algae, with the possible exception of Chaetomorpha aerea, could be expected to be grazer-resistant because of their chemical constituents. Sargassum decipiens is reported to prefer moderately sheltered waters (Womersley 1981). Group 2 contains four species epiphytic on Xiphophora (i.e. Bangia sp., Hypnea episcopalis, Polysiphonia brodiaei and Ceramium $\mathrm{sp}$.) but this is less than half the recorded epiflora (appendix) or, indeed, half of Species Group 2.

Figure 4 shows these species arranged on the first two principal co-ordinate axes of their distance matrix (incorporating $45.7 \%$ of the variance). The same plot is reproduced in figure 5 , with contours of distance, from the dendrogram, drawn around the species locations. Apart from two internally highly similar and externally discrete groups (corresponding to Species Groups 6 and 8 of figure 3 ), these figures show that the species groups are rather diffuse and poorly defined. The first axis appears to be separating species Group 6 from the remainder of the algae, while the other species groups are more clearly arranged on the second axis [from Group 2 (positive), through Groups 8,1 , 5 and 9 , to a cluster containing Groups 3,4 and 7 (negative)].

When these classifications of algal species and sites are combined in nodal analysis (table 4, p. 206), more relationships can be seen. No site group is represented by a single species group, and the larger site groups contain at least one species from most groups; however, some species groups 


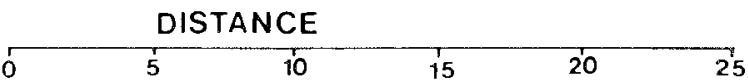

Chaetomorpha aerea Sargassum decipiens

Sargassum sonderi

Corallina pilulifera

Zonaria

Bangia

Encrusting algae

Hypnea

2 Gigartina

Cystophora subfarcinata

Perithalia

Polysiphonia

Ceramium

Sargassum juvenile sp.

Unknown B

3 Bryopsis foliosa

Ulva rigida

Gelidium pusillūm

Unknown D

4 Cladophora subsimplex

Durvillaea

Chaetomorpha coliformis

Ballia

Gelidium austrāe

$5 \quad$ Ulva lactuca

Phyllospora

Corallina officinalis

Caulerpa simpliciuscúla Bryopsis minor

Scytosiphon

Caulerpa geminata

6 Caulerpa brownil

Enteromorpha

Cladophora rhizodonioides

Pterocladia pinnata

Unknown A

Champia

Wranglia

Codium

Sargassum vestitum

Laurencia elata

Gracilaria

$7 \quad$ Ulva laetevirens

Laurencia tasmanica

Acrocarpia

Haliptilon

Cystophora moniliformis

Cystophora xiphocarpa

Pterocladia capillacea

Jeannerettia

Unknown C

Cystophora retroflexa

8 Sargassum verruculosum

Lessonia

Carpoglossum

Chaetomorpha sp.

- Hormosira

Plocamium

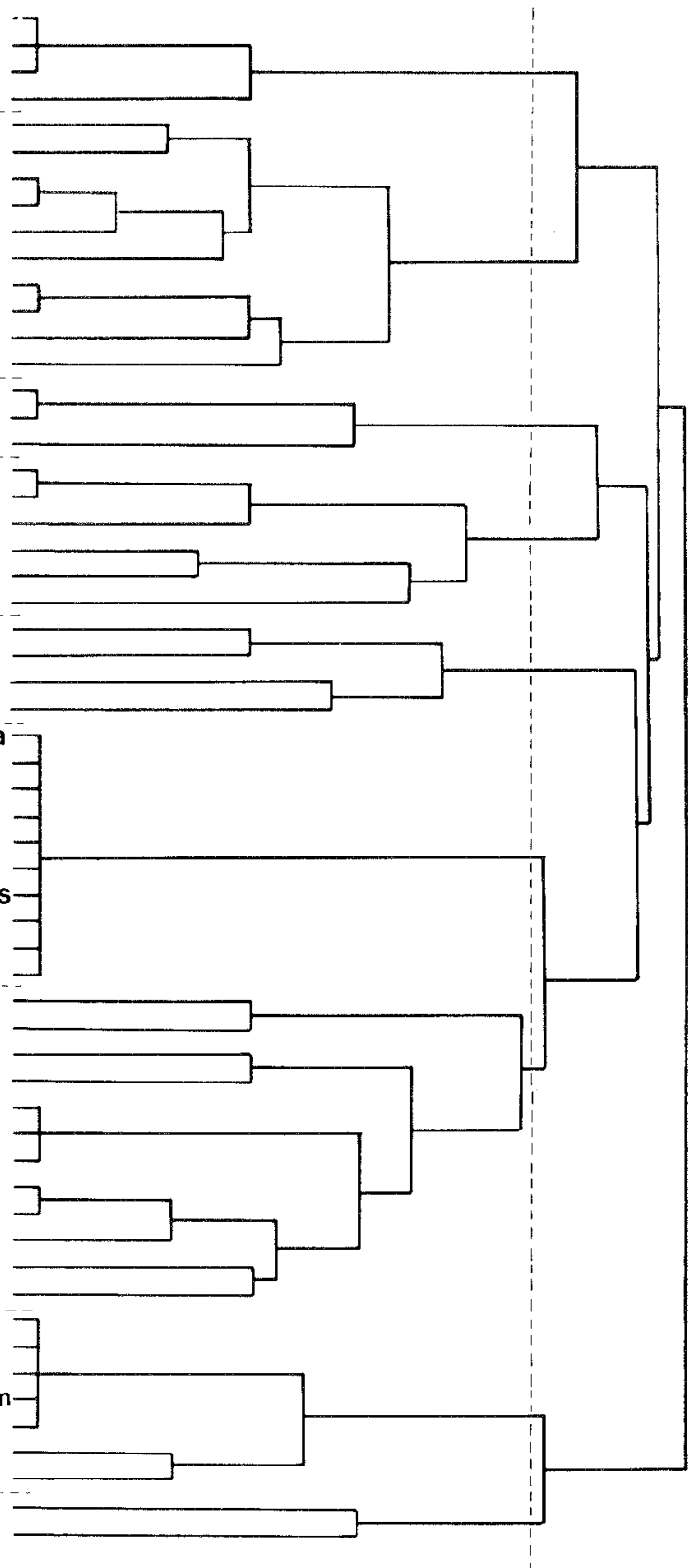

FIG. 3 -A dendrogram of the algal species classified by the sites at which they occur.

Full names of the species are given in table 2. 


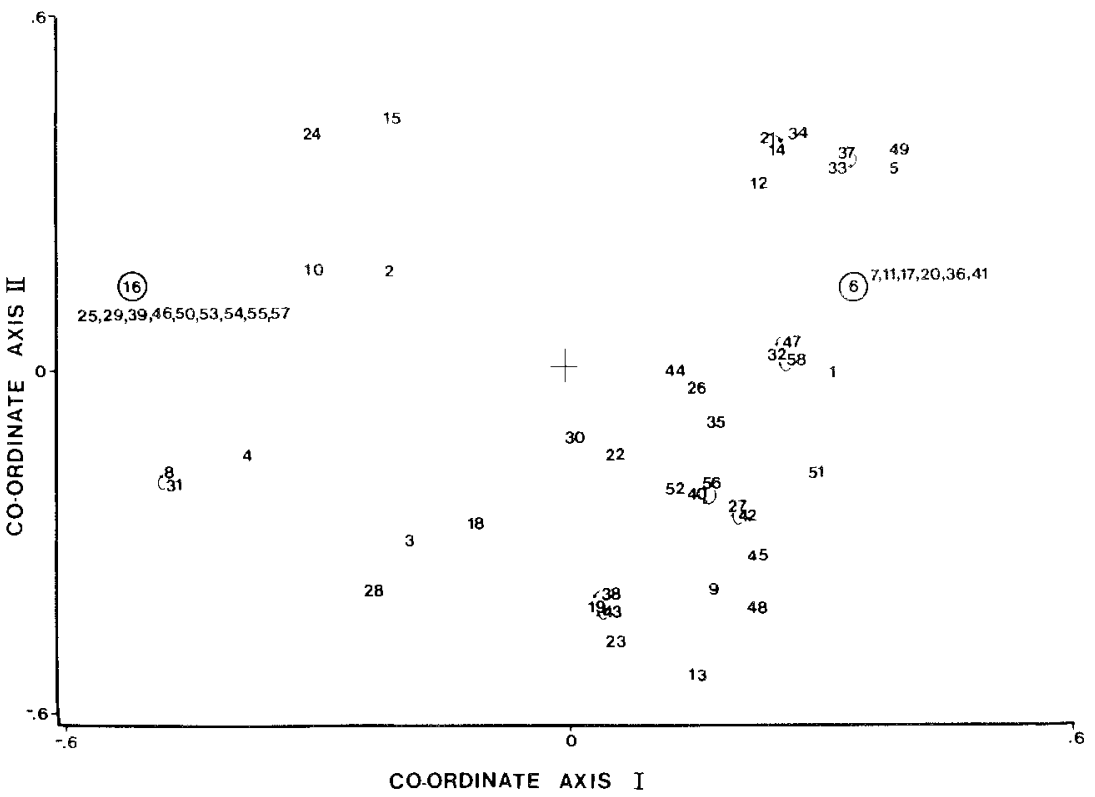

FIG. 4 - A plot of the algal species on the first two principal co-ordinate axes. Species codes are given in table 2. Arrows indicate one or two overlapping values, open circles indicate many overlapping values with the species listed adjacent to the circles.

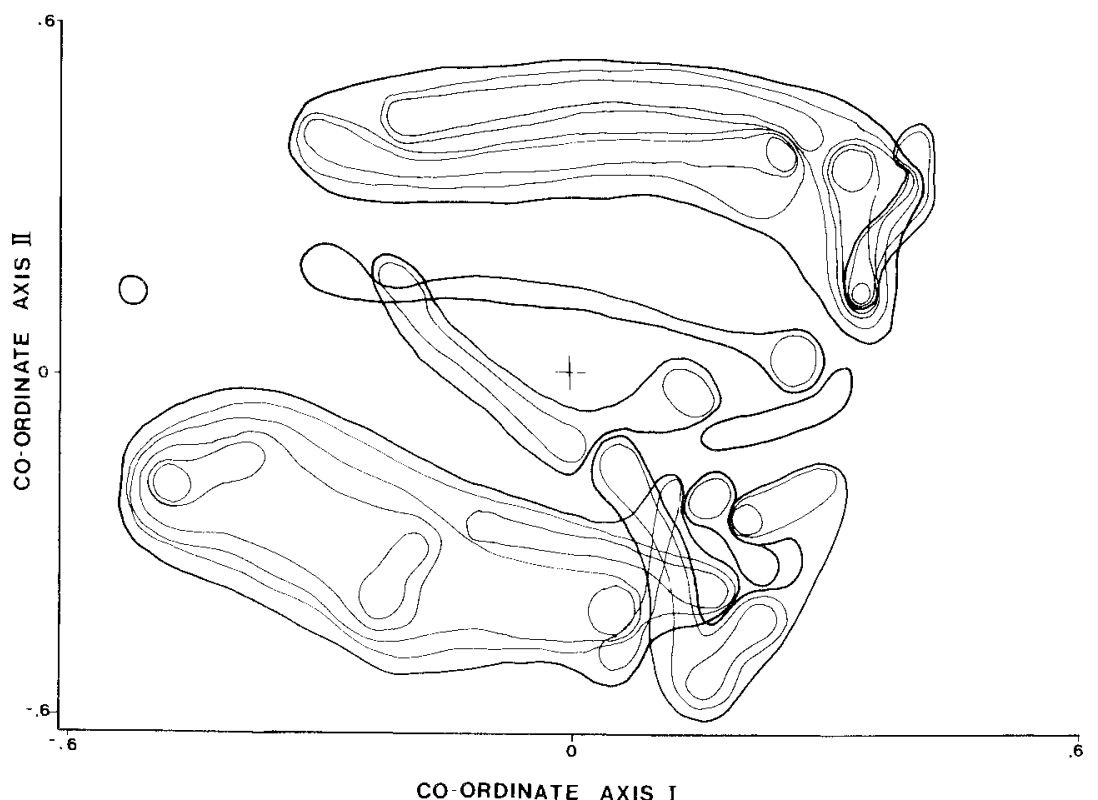

FIG. 5 - Distance contours (refer to dendrogram in fig. 3) drawn around the species groups (fig. 4) plotted on the first two principal co-ordinate axes. Bold lines indicate the grouping at the distance (20) chosen for group definition. 
are confined to particular site groups. Species Group 1, representing some of the possibly grazerresistant plants, was found only at Site Group A, the D'Entrecasteaux Channel, and indeed only at Verona Sands (table 2) in the mouth of the Huon River. Similarly, Species Group 6 is exclusive to Bluff Hill Point. This explains the distinction of this latter group in figures 4 and 5, though only in terms of the analysis and not biologically.

Species Group 2, including four epiphytes, is almost entirely confined to the relatively sheltered waters of the D'Entrecasteaux Channel. Species Groups 3 and 4, on the other hand, are largely absent from those areas, preferring exposed shores (Site Groups C and D) or western shores (Site Groups D and E) respectively. Thus, the second axis in figures 4 and 5 serves to distinguish algae with sheltered, eastern preferences from those with exposed or western tendencies.

Species Group 5 is oddly spread between the D'Entrecasteaux Channel and the Northeast regions. Inspection of table 2 shows it to be composed of two widespread species and two individual species with complete fidelity to Site Groups C and D respectively. Its tabulated constancies (table 4) are, therefore, rather misleading.

Group 7 is widespread, but was found particularly at Skeleton Bay and the exposed western coast. Group 8 was found in the Channel and in both exposed and sheltered western areas. These latter relationships may only be summarising random fluctuations.

When table 4 is examined in the reverse direction, the exposed, western shores of Site

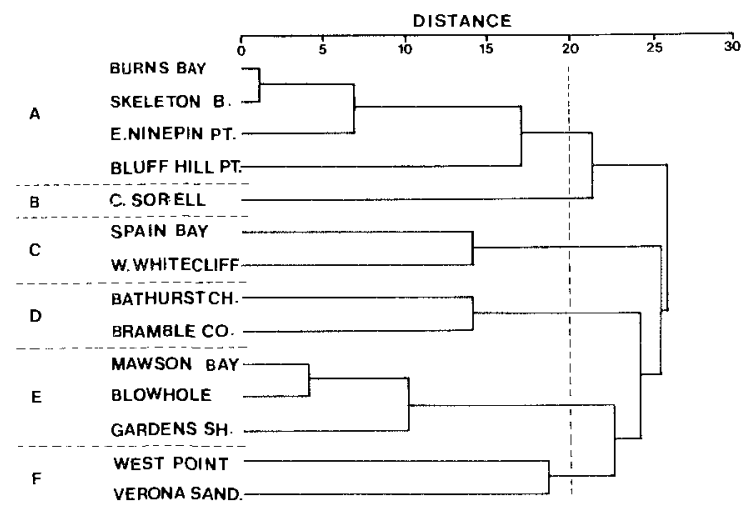

FIG. 6 - A dendrogram of the study sites classified by animal species occurrences at the sites.
Group D are characterised by Species Groups 3, 4 and 7 , including the sublittoral fringe indicator species Durvillaea potatorum. Of these, only Species Group 4 contributes markedly to the Port Davey tannin-influenced southwestern sites, while the exposed northeastern sites share Species Group 3 and add Groups 5 and 9. The latter plus Group 8 are found at the mouth of Port Davey.

In summary, Species Groups 5, 7 and 8 may be, collectively, the "normal" algal inhabitants of the Xiphophora subzone, to which are added Groups 3 and 4 on exposed southern and western shores, Groups 3 and 9 on exposed northeastern shores, Groups 4 and 9 at the mouth of Port Davey, and Group 2 on sheltered eastern shores.

The five "core" species, identified above through individual distributions, fall into Groups 2, 4, 5, and 7 , so that there is no close congruence between these two ways (individual versus assemblage) of viewing the community.

The remaining unusual feature in these data is the presence of Species Group 6 exclusively at Bluff Hill Point. Some of these species, especially the Caulerpa, are usually found at greater depths (Edgar 1983a) though $C$. brownii often occurs in intertidal pools (Bennett \& Pope 1960). At Bluff Hill Point they form a dense turf around the Xiphophora clumps. These plants probably represent the "algal turf" of exposed lower midlittoral zones described by Bennett \& Pope (I960), into which Xiphophora and other species are raised by the extreme wave action at this most exposed of sites.

\section{Fauna}

The analyses of faunal data are less readily explicable. The dendrogram of sites (fig. 6) shows few interpretable clusters. Site Group D comprises the Port Davey tannin-influenced sites and Group E contains only exposed sites, but the remainder of the Groups are of mixed site characteristics. Ordination of these sites (fig. 7) shows that the regions are largely non-overlapping in the space defined by the first two principal co-ordinate axes $(43.9 \%$ of the variance), but each region occupies a very elongated area, suggesting variable faunal composition. The second axis is clearly negatively related to wave exposure, but the first is not readily interpretable.

The dendrogram of animal species (fig. 8) is more clearly divided into clusters, though they are not biologically interpretable. Ordinating these species on the first two principal co-ordinate axes 


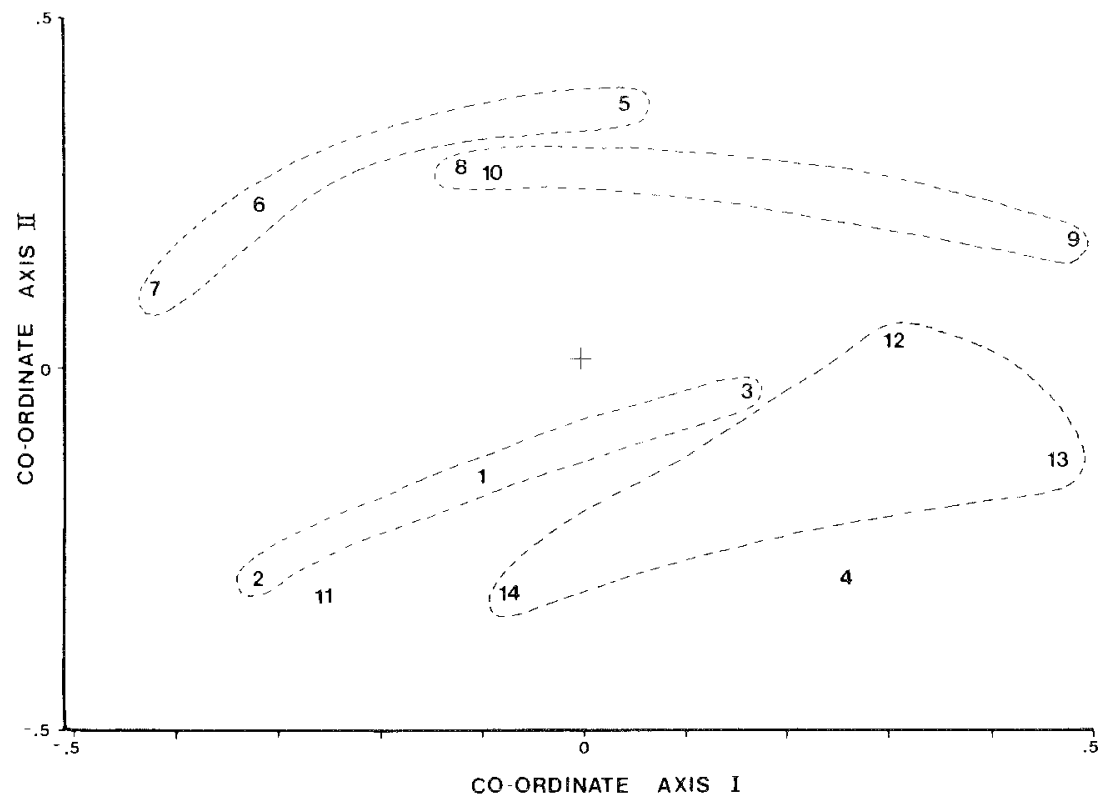

FIG. 7 - A plot of the study sites on the first two principal co-ordinate axes based on a distance matrix of animal occurrence. For site codes see table 1 .

(which explain $52.5 \%$ of the variance - fig. 9) does show a series of discrete groups, generally following the clusters but displaying more complex relationships.

As with the algal analyses, the nodal analysis (table 5, p. 206) is much more useful. Two species groups, 3 and 5, are more-or-less ubiquitous. Indeed, these contain five of the six "core" animal species of the Xiphophora subzone. However, both groups are very diffuse (fig. 9) and the species within them probably have little in common beyond their broad distributions.

The remaining species groups are highly specialised in their sites. Species Groups 1,2 and 4 are the typical animals of the Xiphophora subzone on exposed shores, with Groups 1 and 2 being the species of southern and western areas, while Group 4 comprises those of the northeast.

Species Group 7 was found only at West Point and Bluff Hill Point, the two very exposed northwestern Tasmania sites. It might, therefore, be expected to be associated with Species Groups 1 and 2, though this is not clear in the ordination, suggesting that these two headlands are ecologically less extreme for animals than the Mawson Bay site.
Species Groups 6 and 10 were found primarily at Site Group D, the tannin-influenced Port Davey area sites. Group 10 was characteristic of the very sheltered and very tannin-influenced Bathurst Channel site, though some of its members were also found at the possibly somewhat brackishwater-influenced sites of Verona Sands and Burns Bay. Group 6 was, however, found primarily at the Bramble Cove site (an exception being the anemone Circophorus, which is widespread). These species groups can therefore be described as the southwestern or perhaps tannin- or brackish-watertolerant species.

Species Group 8 was found largely at Site Group $F$ and, within this, almost exclusively at Verona Sands (the link between this site and West Point being here shown to rely on two relatively widespread sponges, Tethya and the unidentified poriferan species, and the gastropod Turbo undulatus. This species group probably represents the species of areas with boulder substrates, limited wave action and some brackish-water influence. The starfish Paranepanthia grandis is known from mainland Australia, but in Tasmania it has only been found in the D'Entrecasteaux Channel and surrounding areas (Dartnall 1980). 
DISTANCE

\begin{tabular}{llllll}
\hline 0 & 5 & 10 & 15 & 20 & 25
\end{tabular}

Austromytilus

Opisthobranchia sp.A

Ischnochiton resplendens

Patelloida insignis

1 Lasaea

Polychaeta spp

Plaxiphora

Patiriella calcar

Notoacmea petterdi

Catomerus

Patelloida alticostata

2 Patiriella vivipara

Melarapha

Calicarcinus

$3 \quad$ Patelloida victoriana

Electra

Notoacmea corrodenda

Dicathais

5 Amphoroidea

Porifera sp.A

Mytilus

Epopella

6 Cellaria

Paragrapsis

Circophorus

Litozamia

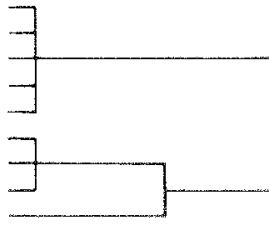

Dentımitrella pulla

Tethya

Subninella

Anthozoa sp.A

Haploplax

Paranepanthia

Petrolisthes

Notomithrax

Ischnochiton variegatus

Rhabdozoum

Sertularia

Bryozoa sp.B

Emma

Ischnochiton australis

Cominella

Dentimitrella sp. A

Chlamys

9 Membranipora sp.A

Dentimitrella vineta

Dentimitrella tayloriana

Clanculus limbatus

Clanculus plebejus

Phasianella

Phasianotrochus irisodontes

Bryozoa sp.A

Ischnochiton subviridis

Micrastraea

Tosia

Notoácóéa flammēéa

10 Lepsiella

Austrocochlea constricta

Tugalia
Pisces

11

sp. A
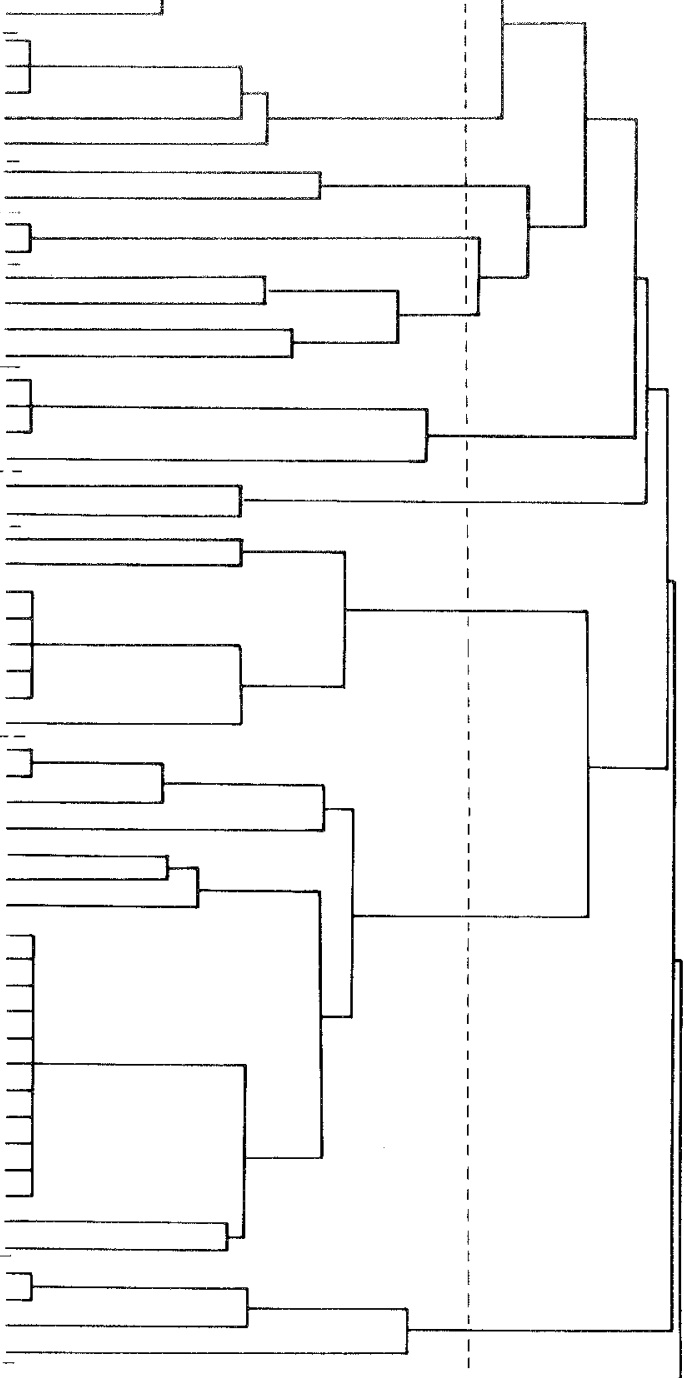

FIG. 8- A dendrogram of the animal species classified by the sites at which they occur. Full names of the species are given in table 3. 


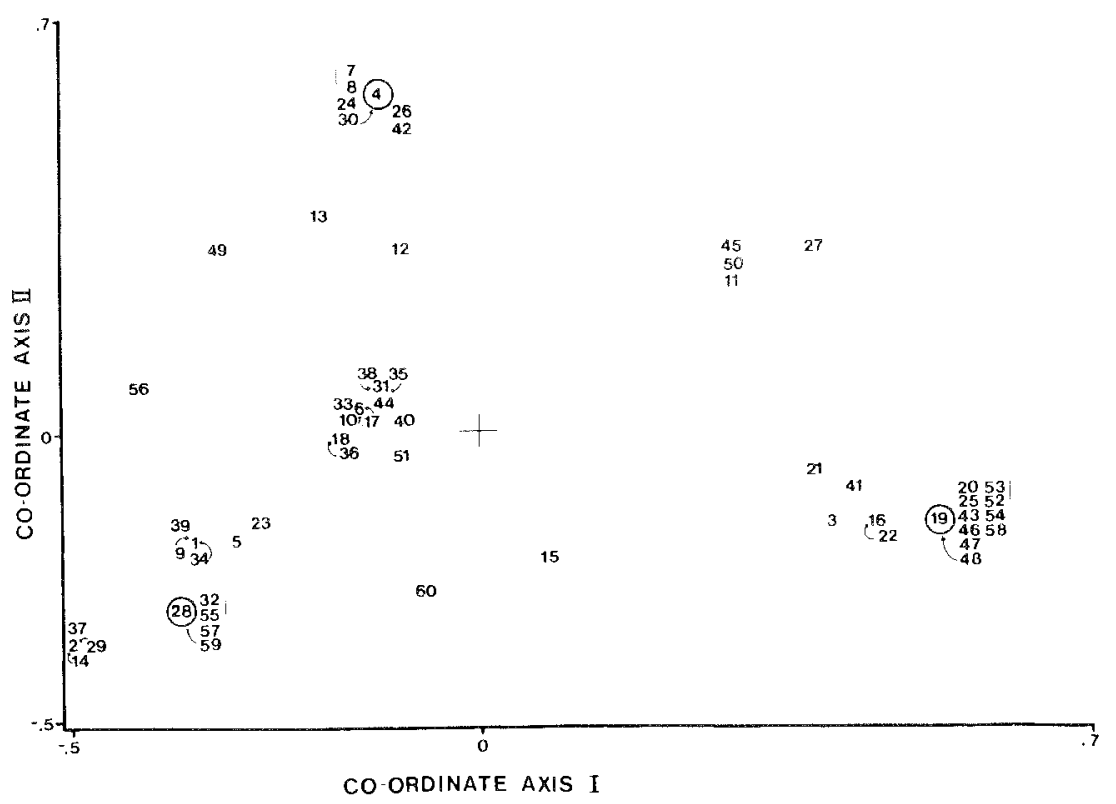

FIG. 9 - A plot of the animal species on the first two principal co-ordinate axes. Species codes are given in table 3. Arrows indicate one or two overlapping values, open circles indicate many overlapping values with the species listed adjacent to the circles.

Species Group 9, the largest, had a strong preference for Site Group C (Spain Bay and White Cliff). Indeed, every species in the group occurred at White Cliff and more than half occurred nowhere else. This species group includes five of the seven byrozoans found plus the only hydroid, suggesting that the D'Entrecasteaux Channel (and, to a less extent, Spain Bay) are desirable areas for small colonial filter feeders, perhaps utilising flocculent material from the river run-off.

The species group is shared with the generally similar site at Spain Bay ( four species), Ninepin Point and Verona Sands (three species), Burns Bay and Bathurst Channel (one species each) and, more surprisingly, the Blowhole, Bluff Hill Point, West Point and Gardens Shoal (three species: Emma triangula, Micrastraea aurea, Tosia magnifica). Only two species which occur at White Cliff are not in this species group, showing that the UPGMA, SAHN cluster has been driven by the large number of close similarities in this unit.

Species Group 11, the only fish in the analyses, was found only at Cape Sorell. The other species at that site were all rather widespread and it is the presence of this fish which separates Cape Sorell from the other exposed west coast sites in figure 6 .

This interpretation of the nodal analysis also allows some explanation of the failure of the cluster analysis of sites using the animal data. A combination of some common and widespread species with other rare or patchy ones (possibly exacerbated by the use of binary data) caused some disparate sites to cluster together (e.g. West Point with Verona Sands, Bluff Hill Point with Group A) and separated Cape Sorell from the other exposed west coast sites. 


\section{TABLE 2}

The Occurrence of Algal Species at each of the Sampling Sites

\begin{tabular}{|c|c|c|c|c|c|c|c|c|c|c|c|c|c|c|c|}
\hline \multirow{2}{*}{$\begin{array}{l}\text { Division } \\
\text { Order } \\
\text { Species }\end{array}$} & \multirow[b]{2}{*}{$\begin{array}{l}\text { Speries } \\
\text { code }\end{array}$} & \multirow[b]{2}{*}{1} & \multirow[b]{2}{*}{2} & \multirow[b]{2}{*}{3} & \multirow[b]{2}{*}{4} & \multirow[b]{2}{*}{5} & \multicolumn{4}{|c|}{ Sire code* } & \multirow[b]{2}{*}{10} & \multirow[b]{2}{*}{1} & \multirow[b]{2}{*}{$\mathbb{2}$} & \multirow[b]{2}{*}{13} & \multirow[b]{2}{*}{14} \\
\hline & & & & & & & 6 & 7 & 8 & 9 & & & & & \\
\hline \multicolumn{16}{|l|}{ Chlorophyta } \\
\hline \multicolumn{16}{|l|}{ Ulvales } \\
\hline Ulva laetevirens (L.) Aresch. & 43 & + & - & - & - & - & $-\ldots$ & - & - & - & - & - & - & - & - \\
\hline U. lactuca $\mathrm{L}$ & 44 & $\ldots$ & - & - & - & - & - & - & - & - & - & - & - & - & + \\
\hline U. rigida (L.) C.Ag. & 45 & - & - & - & + & - & - & - & - & - & $-\cdots$ & + & + & - & - \\
\hline Enteromorpha intestinalis (L.) Link. & 46 & - & - & + & - & - & - & - & - & - & - & -- & - & - & - \\
\hline \multicolumn{16}{|l|}{ Cladophorales } \\
\hline Chaetomorpha aerea (Dillwyn) Kuetz. & 47 & - & - & - & - & - & - & - & + & - & - & - & - & - & - \\
\hline C. coliformis (Mont.) Kuetz. & 48 & - & + & - & + & - & + & - & - & - & - & + & - & - & - \\
\hline C. sp. & 49 & - & - & - & - & + & - & + & - & - & + & - & - & - & - \\
\hline Cladophora rhizodonioidea Van den Hook \& Wom. & 50 & - & - & + & - & - & - & - & - & - & - & - & - & - & - \\
\hline C. subsimplex Kuetz. & 51 & - & - & - & + & - & - & - & + & - & - & - & - & - & - \\
\hline \multicolumn{16}{|l|}{ Codiales } \\
\hline Codium fragile (Sur.) Hariot & 52 & - & + & - & - & - & - & - & - & - & - & - & - & - & - \\
\hline \multicolumn{16}{|l|}{ Caulerpales } \\
\hline Caulerpa geminata Harv. & 53 & - & - & + & - & - & - & - & -- & - & - & - & - & - & - \\
\hline C. brownii (C.Ag.) Endl. & 54 & - & - & + & - & - & - & - & - & - & - & - & - & - & - \\
\hline C. simpliciuscula (Turner) C.Ag. & 55 & - & - & + & - & - & - & - & - & - & - & - & - & - & - \\
\hline Bryopsis foliosa Sonder & 56 & - & - & - & - & - & - & - & - & - & - & + & - & - & - \\
\hline B. minor Wom. & 57 & - & - & + & - & - & - & - & - & - & - & - & - & - & - \\
\hline \multicolumn{16}{|l|}{ Rhodophyta } \\
\hline Ceramiales & & & & & & & & & & & & & & & \\
\hline Laurencia elata (C.Ag.) Harv. & 18 & + & + & + & - & - & - & - & + & - & - & + & + & - & - \\
\hline L. tasmanica Hook. \& Harv. ex Harv. & 19 & + & - & - & - & - & - & - & - & - & - & - & - & - & - \\
\hline Jeannerettia lobata Hook \& Harv..$^{\ddagger}$ & 20 & - & - & - & - & + & - & - & - & - & - & - &.- & - & - \\
\hline Polysiphonia brodiaei (Dillw.) Sprengel. ${ }^{\S}$ & 21 & - & - & - & - & - & - & - & - & - & + & - & - & - & - \\
\hline Ballia callitricha (Ag.) Mont. & 22 & + & - & + & + & + & + & + & + & - & - & - & - & - & - \\
\hline Wrangelia spareopsis & 23 & + & + & - & - & - & - & - & - & - & - & - & - & - & - \\
\hline Ceramium sp. ${ }^{\ddagger}$ & 24 & - & - & + & - & - & - & - & - & - & - & - & - & - & - \\
\hline Rhodymeniales & & & & & & & & & & & & & & & \\
\hline Champia viridis C.Ag. & 25 & - & - & + & - & - & - & - & - & - & - & - & - & - & - \\
\hline Gelidiales & & & & & & & & & & & & & & & \\
\hline Gelidium australe J.Ag. ${ }^{\ddagger}$ & 26 & - & - & - & - & - & - & - & - & + & - & - & + & - & + \\
\hline G. pusillum (Stack.) Le Jol. & 27 & - & - & - & + & - & - & - & - & - & - & - & - & - & - \\
\hline Pterocladia capillacea (Gmel.) Born. \& Thur. & 28 & + & - & + & + & - & - & - & - & - & - & + & - & - & - \\
\hline P. pinnata (Huds.) Pap. & 29 & - & - & + & - & - & - & - & - & - & - & - & - & - & - \\
\hline Cryptonemiales & & & & & & & & & & & & & & & \\
\hline Corallina officinalis $\mathrm{L}$. & 30 & - & + & + & + & - & - & - & + & + & - & + & $\cdot-$ & - & + \\
\hline C. pilulifera Post. \& Rupr. & 32 & - & - & - & - & - & - & - & + & - & - & - & - & - & - \\
\hline Haliptilon roseum (Lamarck) Gabary \& Johansen & 31 & + & - & + & - & - & - & - & - & - & - & - & - & - & - \\
\hline Unident. crustal algal sp. & 33 & - & - & - & - & - & - & - & + & + & + & + & - & - & - \\
\hline Bangiales & & & & & & & & & & & & & & & \\
\hline Bangia sp. ${ }^{\ddagger}$ & 34 & - & - & - & - & - & - & - & - & + & + & - & - & - & - \\
\hline
\end{tabular}




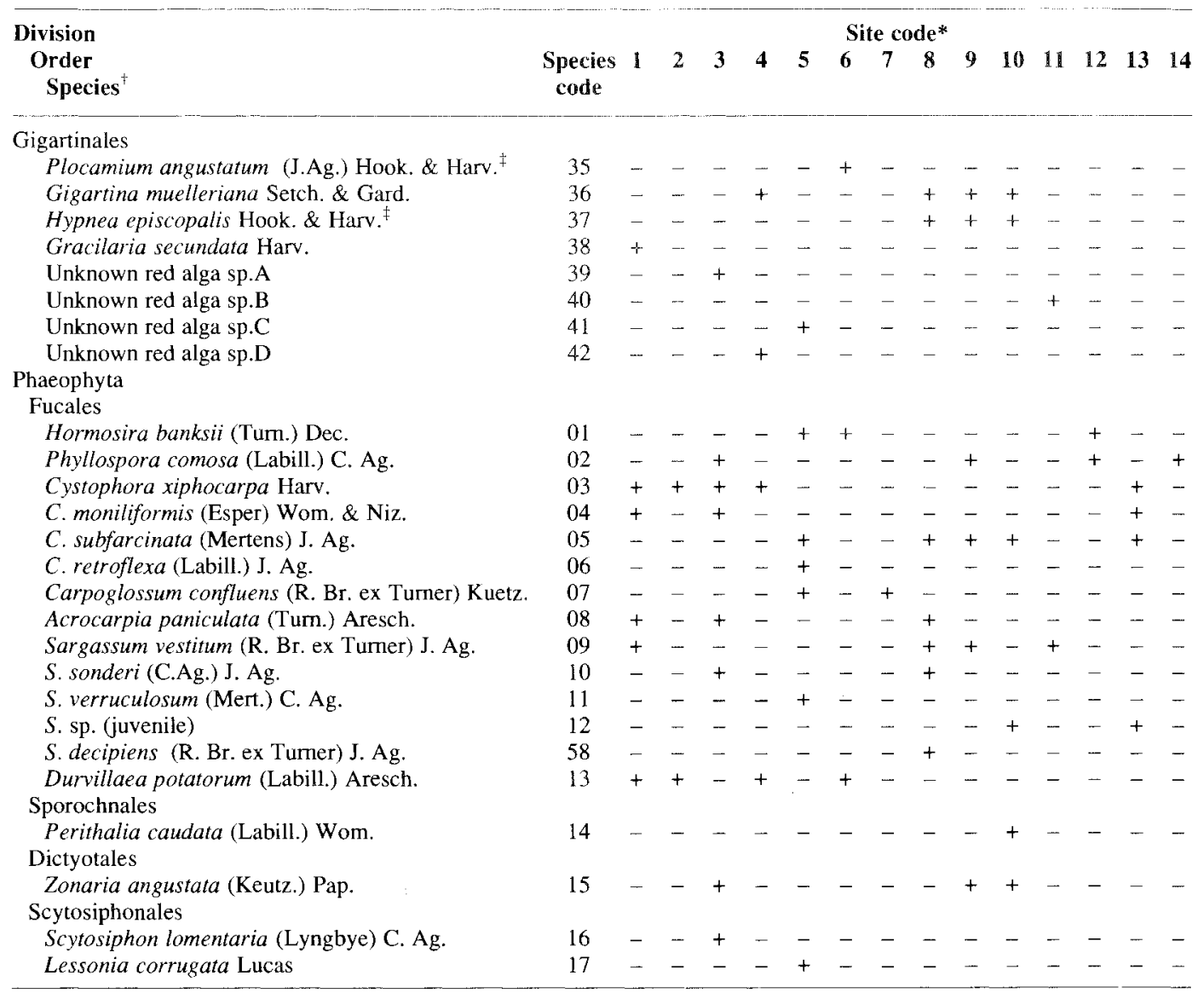

* See table 1.

$\dagger$ Nomenclature follows identification guides cited in text and hence may exclude some recent unpublished revisions.

\# Epiphytic species.

$\S$ Free-living species found among fronds of Xiphophora. 
TABLE 3

The Occurrence of Animal Species at Each of the Sampling Sites

\begin{tabular}{l}
$\begin{array}{l}\text { Phylum** } \\
\text { Class } \\
\text { Species }\end{array}$ \\
\hline
\end{tabular}

Porifera

Demospongiae

Tethya sp.A

Callyspongia clathrata Dendy

Unident poriferan sp.

$\begin{array}{lllllllllllllll}11 & + & - & - & - & + & - & - & + & - & + & - & - & - & - \\ 12 & - & - & + & - & + & - & - & + & + & - & - & + & + & - \\ 13 & + & - & - & - & - & - & + & + & - & - & - & - & - & +\end{array}$

Coelenterat

Hydrozoa

Sertularia marginata (Kirchenpauer) ${ }^{\S}$

Zoantharia

Circophorus nutrix (Stuckey) ${ }^{8}$

Unident anthozoan sp.

Annelida

Polychaet?

Unident. polychaete sp.

Crustacea

Cirripe dia

Catomerus polymerus (Darwin)

Epopella simplex (Darwin)

Malacostraca

Halicarcinus ovatus (Stimpson)

Paragrapsis quadridentatus (Milne Edwards)

Petrolisthes elongatus (Milne Edwards)

Notomithrax ursus (Herbst)

Amphoroidea elegans (Baker)"

Mollusca

Polyplacophora

Ischnochiton subviridis Iredale \& May

I. variegatus (Adams \& Angus)

I. australis (Sowerby)

I. resplendens Bednall \& Mathews

Plaxiphora albida Blainville

Haploplax mayi Pilsbry

Gastropoda

Unident. opisthobranchian sp.

Tugali cicatricosa Adams

Patelloida insignis (Menke)

$P$. victoriana (Singleton)

$P$. alticostata (Angas)

Notoacmea flammea (Quoy \& Gaimard)

$N$. corrodenda (May)

$N$. petterdi (Tenison Woods)

Lepsiella vinosa (Lamarck)

Thais textilosa (Lamarck)
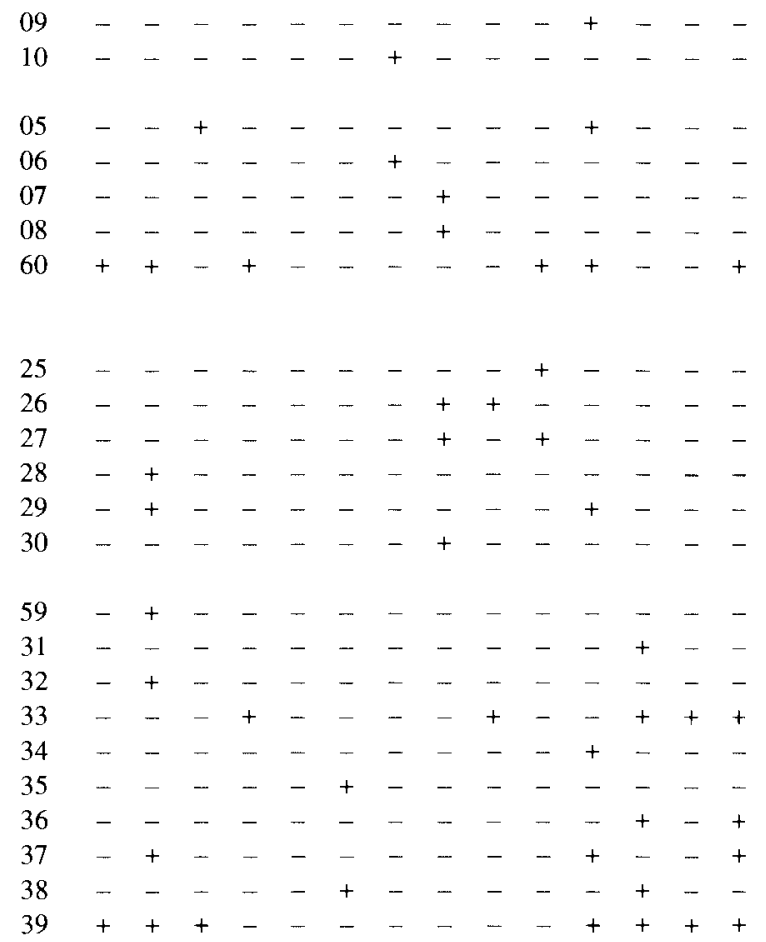


\begin{tabular}{|c|c|c|c|c|c|c|c|c|c|c|c|c|c|c|c|}
\hline \multirow{2}{*}{$\begin{array}{l}\text { Phylum* } \\
\text { Class } \\
\text { Species }\end{array}$} & \multirow[b]{2}{*}{$\begin{array}{c}\text { Species } \\
\text { code }\end{array}$} & \multirow[b]{2}{*}{1} & \multirow[b]{2}{*}{2} & \multirow[b]{2}{*}{3} & \multirow[b]{2}{*}{4} & \multirow[b]{2}{*}{5} & \multicolumn{4}{|c|}{ Site code ${ }^{\frac{1}{+}}$} & \multirow[b]{2}{*}{10} & \multirow[b]{2}{*}{11} & \multirow[b]{2}{*}{12} & \multirow[b]{2}{*}{13} & \multirow[b]{2}{*}{14} \\
\hline & & & & & & & 6 & 7 & $\mathbf{8}$ & 9 & & & & & \\
\hline Litozamia brazieri (Tenison Woods) & 40 & + & - & + & - & - & - & - & - & - & - & - & - & - & - \\
\hline Micrastraea aurea (Jonas) & 41 & + & - & - & - & - & - & - & - & - & + & - & - & - & - \\
\hline Turbo undulatus Solander & 42 & + & - & - & - & - & - & - & + & - & - & - & - & - & - \\
\hline Phasianella australis (Gmelin) & 43 & - & - & - & - & - & - & - & - & - & + & - & - & - & - \\
\hline Austrocochlea constricta (Lamarck) & 44 & - & - & - & - & - & + & - & + & - & - & - & - & - & - \\
\hline A. odontis (Wood) & 45 & - & - & - & - & - & - & - & - & - & + & - & + & - & - \\
\hline Phasionotrochus irisodontes (Quoy \& Gaimard) & 46 & - & - & - & - & - & - & - & - & - & + & - & - & - & - \\
\hline Clanculus limbatus (Quoy \& Gaimard) & 47 & - & - & - & - & - & - & - & - & - & + & - & - & - & - \\
\hline C.plebejus (Philippi) & 48 & - & - & - & - & - & - & - & - & - & + & - & - & - & - \\
\hline Melarapha unifasciata (Goray) & 49 & - & - & - & - & $\ldots$ & - & - & + & - & - & + & - & & - \\
\hline Cominella lineolata (Lamarck) & 50 & - & - & - & - & - & + & - & + & - & + & - & - & - & - \\
\hline Dentimitrella pulla (Gaskoin) & 51 & - & - & + & - & - & - & - & - & - & - & - & - & - & - \\
\hline D. vineta & 52 & - & - & - & - & - & - & - & - & - & + & - & - & - & - \\
\hline D. tayloriana & 53 & - & - & - & - & - & - & - & - & - & + & - & - & - & - \\
\hline D. sp. & 54 & - & - & - & - & - & - & - & - & - & + & - & - & - & - \\
\hline \multicolumn{16}{|l|}{ Bivalvia } \\
\hline Lasaea australis (Lamarck) & 66 & - & + & - & - & - & - & - & - & - & - & - & - & - & - \\
\hline Mytilus edulis planulatus (Lamarck) & 56 & - & + & - & - & - & + & + & + & - & - & + & - & - & + \\
\hline Austromytilus rostratus (Dunker) & 57 & - & + & - & - & - & - & - & - & - & - & - & - & - & - \\
\hline Chlamys asperrimus (Lamarck) & 58 & - & - & - & - & - & - & - & - & - & + & - & - & - & - \\
\hline \multicolumn{16}{|l|}{ Bryozoa } \\
\hline \multicolumn{16}{|l|}{ Gymnolaemata } \\
\hline Emma triangula Haastings & 15 & - & - & + & - & + & - & - & - & - & + & + & - & - & + \\
\hline Rhabdozoum wilsoni Hincks ${ }^{\S}$ & 16 & - & - & - & - & + & - & - & - & - & + & - & - & - & - \\
\hline Cellaria sp. $^{\S}$ & 17 & - & - & - & - & - & - & + & - & - & - & - & - & - & - \\
\hline Electra pilosa (L.) $)^{\S}$ & 18 & - & - & - & - & - & - & - & - & - & - & - & - & - & + \\
\hline Membranipora sp. ${ }^{\S}$ & 19 & - & - & - & - & - & - & - & - & -- & + & - & - & - & - \\
\hline Unident. bryozoan $\mathrm{sp} . \mathrm{A}^{\S}$ & 20 & - & - & - & - & - & - & - & - & - & + & - & - & - & - \\
\hline Unident. bryozoan sp. $\mathrm{B}^{\S}$ & 21 & - & - & - & - & + & - & - & - & + & + & - & - & - & - \\
\hline \multicolumn{16}{|l|}{ Echinodermata } \\
\hline \multicolumn{16}{|l|}{ Stelleroidea } \\
\hline Patiriella vivipara Dartnall & 01 & - & - & - & - & - & - & - & - & - & - & + & - & - & - \\
\hline P. calcar Lamarck & 02 & - & - & + & - & - & - & - & - & - & - & + & - & - & - \\
\hline Tosia magnifica (Muller \& Troschel) & 03 & - & - & - & + & - & - & - & - & - & + & - & - & - & - \\
\hline Paranepanthia grandis Clark & 04 & - & - & - & - & - & - & - & + & - & - & - & - & - & - \\
\hline \multicolumn{16}{|l|}{ Chordata } \\
\hline \multicolumn{16}{|l|}{ Pisces } \\
\hline Unident. clingfish & 61 & - & - & - & + & - & - & - & - & - & - & - & - & - & - \\
\hline
\end{tabular}

The following Crustacea were also found: Isychromene sp. A and B ?, Dynamenopsis sp. ${ }^{\uparrow}$, Cymodoce coronata (Leach) , Euidotea peronii Milne Edwards ", Crabysoz elongatus (Miers) ", Pontogeneidae Genus A sp.A ?, Podoceridae Genus A sp. A ${ }^{\Uparrow}$

* Classification of invertebrates follows George \& George (1979).

$\uparrow$ Nomenclature follows identification guides cited in text and hence may exclude some recent unpublished revisions.

‡ See table 1.

$\S$ Epiphytic species.

If Free-living species found among fronds of Xiphophora. 
TABLE 4

The Constancy and Fidelity of the Algal Species Groups to the Site Groups

\begin{tabular}{|c|c|c|c|c|c|c|c|c|c|}
\hline \multirow{2}{*}{$\begin{array}{l}\text { Site } \\
\text { group }\end{array}$} & \multicolumn{9}{|c|}{ Species group* } \\
\hline & 1 & 2 & 3 & 4 & 5 & 6 & 7 & 8 & 9 \\
\hline \multicolumn{10}{|c|}{ Constancy } \\
\hline A & 0.33 & 0.67 & 0 & 0.11 & 0.25 & 0 & 0.06 & 0.10 & 0 \\
\hline B & 0 & 0.20 & 0 & 0 & 0 & 0 & 0.17 & 0 & 0 \\
\hline $\mathrm{C}$ & 0 & 0 & 0.17 & 0 & 0.75 & 0 & 0.04 & 0 & 0.25 \\
\hline $\mathrm{D}$ & 0 & 0.07 & 0.22 & 0.33 & 0.17 & 0.17 & 0.36 & 0.08 & 0.08 \\
\hline $\mathrm{E}$ & 0 & 0 & 0 & 0.33 & 0 & 0 & 0 & 0.14 & 0.50 \\
\hline \multicolumn{10}{|c|}{ Fidelity } \\
\hline A & 5.00 & 3.53 & 0 & 0.73 & 1.09 & 0 & 0.46 & 1.67 & 0 \\
\hline $\mathrm{B}$ & 0 & 1.05 & 0 & 0 & 0 & 0 & 1.31 & 0 & 0 \\
\hline $\mathrm{C}$ & 0 & 0 & 2.13 & 0 & 3.26 & 0 & 0.31 & 0 & 1.67 \\
\hline $\mathrm{D}$ & 0 & 0.37 & 2.75 & 2.20 & 0.74 & 5.00 & 2.77 & 1.33 & 0.53 \\
\hline $\mathrm{E}$ & 0 & 0 & 0 & 2.20 & 0 & 0 & 0 & 2.33 & 3.33 \\
\hline
\end{tabular}

* From figure 3 .

TABLE 5

The Constancy and Fidelity of the Faunal Species Groups to the Site Groups

\begin{tabular}{|c|c|c|c|c|c|c|c|c|c|c|c|}
\hline \multirow{2}{*}{$\begin{array}{l}\text { Site } \\
\text { Group }\end{array}$} & \multicolumn{11}{|c|}{ Species group* } \\
\hline & $\mathbf{1}$ & 2 & 3 & 4 & 5 & 6 & 7 & 8 & 9 & 10 & 11 \\
\hline \multicolumn{12}{|c|}{ Constancy } \\
\hline A & 0 & 0.05 & 0.88 & 0.13 & 0.19 & 0 & 0.25 & 0.03 & 0.05 & 0.19 & 0 \\
\hline B & 0 & 0 & 0.50 & 0 & 0.25 & 0 & 0 & 0 & 0 & 0 & 1.00 \\
\hline $\mathrm{C}$ & 0 & 0 & 0.25 & 0 & 0.13 & 0.13 & 0 & 0.13 & 0.60 & 0 & 0 \\
\hline D & 0 & 0 & 0 & 0 & 0.38 & 0.63 & 0 & 0 & 0.03 & 0.38 & 0 \\
\hline $\mathrm{E}$ & 0.36 & 0.33 & 0.17 & 0.33 & 0.83 & 0.08 & 0 & 0 & 0.03 & 0 & 0 \\
\hline$F$ & 0 & 0.10 & 0.25 & 0 & 0.63 & 0 & 0.25 & 0.56 & 0.08 & 0.13 & 0 \\
\hline \multicolumn{12}{|l|}{ Fidelity } \\
\hline A & 0 & 0.63 & 2.59 & 1.69 & 0.47 & 0 & 3.13 & 0.25 & 0.38 & 1.62 & 0 \\
\hline B & 0 & 0 & 1.47 & 0 & 0.63 & 0 & 0 & 0 & 0 & 0 & 5.89 \\
\hline $\mathrm{C}$ & 0 & 0 & 0.74 & 0 & 0.33 & 0.93 & 0 & 1.00 & 4.62 & 0 & 0 \\
\hline $\mathrm{D}$ & 0 & 0 & 0 & 0 & 0.95 & 4.50 & 0 & 0 & 0.23 & 3.25 & 0 \\
\hline $\mathrm{E}$ & 6.00 & 4.13 & 0.50 & 4.29 & 2.08 & 0.57 & 0 & 0 & 0.23 & 0 & 0 \\
\hline$F$ & 0 & 1.25 & 0.74 & 0 & 1.58 & 0 & 3.13 & 4.31 & 0.62 & 1.11 & 0 \\
\hline
\end{tabular}

* From figure 3 . 


\section{GENERAL DISCUSSION AND CONCLUSIONS}

This work has identified a number of algal and animal species that are characteristic of the Xiphophora subzone in various areas around Tasmania. These lists are the only description yet available of the assemblage within which Xiphophora lives, as distinct from the wider sublittoral fringe zone. A knowledge of the community composition of this subzone is a necessary prelude to understanding the ecological interactions which drive this system. This study has also examined the patterns of variation within the assemblage and suggested some factors which may control that variation. Both animal and plant species compositions are strongly correlated to wave exposure and, to a lesser extent, to freshwater run-off (in the form of the tannin-stained waters of Port Davey and the less-stained but perhaps more brackish waters from the Huon River). Both groups of organisms also show some inter-regional variations in species composition, though these are not consistent. Amongst the algae, the southwestern area is particularly distinct, while some aspects of floral composition distinguish the northeastern or D'Entrecasteaux Channel sites from other areas. The faunal assemblages differ between all regions but that in the D'Entrecasteaux Channel is particularly distinct.

One of the most prominent results of these analyses is the relative ecological peculiarity of the Xiphophora subzone in the D'Entrecasteaux Channel. This is presumably partly as a result of shelter and the influence of Huon River water. It may also relate to the absence in that region of Durvillaea and other competitive dominants of the sublittoral fringe zone, an absence which permits Xiphophora to expand into a major belt from the extreme low tide line down to one or two metres depth below Lowest Astronomic Tide. This expansion may allow the Xiphophora subzone to encompass parts of the ranges of various sublittoral species. Equally, Xiphophora does not grow above low tide mark in this region, a situation which will again tend to alter the species occurring in its subzone. However, none of these reasons seems sufficient to account fully for the marked difference in species composition, particularly of animals, of the channel sites. Part of the uniqueness of these D'Entrecasteaux Channel species compositions involves the prominent occurrence there of an epifauna on Xiphophora and, to a less marked extent, of an epiflora. D"Antonio (1985) has shown that macroalgal epiphytes are a significant food source for foraging herbivores. The algal epiphytes, which were often concentrated at the base of the plants or in spent conceptacles (cf. Russell \& Veltkamp 1984), may therefore attract and support the gastropods and other animals found uniquely in the region. The reason for the predominance of epiphytes nevertheless remains obscure. Epithoral macroalgae, as a group, are widespread, but they tend to be most common in the upper sublittoral zone on exposed shores (Womersley 1981), in marked contrast to the pattern reported here.

In terms of the lists of species found living with Xiphophora, this study has shown the subzone to have high species richness, in contrast to the conclusions of earlier workers concerning the sublittoral fringe zone as a whole. Much of this increased richness stems from the presence in the Xiphophora subzone of species which Bennett \& Pope (1960) and Edgar (1984) allocated to the floras and faunas of other zones. Most of these are supposed eulittoral species whose ranges are now seen to extend into at least the upper margin of the sublittoral fringe. Fewer sublittoral species extend up through the fringe zone to be found with Xiphophora. The present work has shown that, on Tasmanian shores, the lower eulittoral and sublittoral fringe zones, as defined by their biota, grade into one another.

\section{ACKNOWLEDGEMENTS}

I wish to extend my appreciation to Miss A. Green, Mrs L. Turner (both Tasmanian Museum, Hobart), Dr J. Phillips (Monash University, Victoria), Prof. H.B.S. Womersley (University of Adelaide, South Australia), Mr C. Court (Hobart) and the staff of the Tasmanian Herbarium for helping me with difficult identifications and for cataloguing and lodging the specimen collections. I also wish to thank the captain and crew of the Eye of the Wind for their help in obtaining and preserving the Port Davey collections. Dr T.J. Kenchington assisted with field collections and critically reviewed this manuscript, for which I am grateful. I was in receipt of a Natural Sciences and Engineering Research Council of Canada Postgraduate Scholarship and a University of Tasmania Postgraduate Scholarship. 


\section{REFERENCES}

Alvey, N.G., Banfield, C.F., Baxter, R.I., Gower, J.C., Krzanowski, W.J., Lane, P.W., Leech, P.K., Nelder, J.A., Payne, R.W., Phelps, K.M., Rogers, C.E., Ross, G.J.S., Simpson, H.R., Todd, A.D., Wedderburn, R.W.M. \& WILKINSON, G.N., 1977: GENSTAT. A GENERAL STATISTICAL PROGRAM. Rothamsted Experimental Station, Harpenden, Hertfordshire.

BAARDSETH, E., 1970: A square-scanning, two-stage sampling method of estimating seaweed quantities. Norw. Inst. Seaweed Res. Rep. 33: 41 pp.

BenNetT, I. \& POPE, E.C., 1960: Intertidal zonation of the exposed rocky shores of Tasmania and its relationships with the rest of Australial. Aust. J. Mar. Freshw. Res. 11: 182-221.

BOLD, H.C. \& WynnE, M.J., 1978: INTRODUCTION TO THE ALGAE. Prentice-Hall, New Jersey.

Clifford, H.T. \& Stephenson, W., 1975: $A N$ INTRODUCTION TO NUMERICAL CLASSIFICATION. Academic Press, New York.

Colvocoresses, J.A. \& Musick, J.A., 1984: Species associations and community composition of middle Atlantic Bight continental shelf demersal fishes. Fish. Bull. 82: 295-313.

COTTON, B.A., 1964: SOUTH AUSTRALIAN MOLLUSCA: CHITONS. Government Printer, South Australia.

Cribi, A.B., 1954: The algal vegetation of Port Arthur, Tasmania. Pap. Proc. R. Soc. Tasm. 88: 1-44.

D'Antonio, C., 1985: Epiphytes on the rocky intertidal red alga Rhodemela larix (Turner) C.Agardh: negative effects on the host and food for herbivores. J. Exp. Mar. Biol. Ecol. 86: 197-218.

DARTNALL, A., 1980. TASMANIAN ECHINODERMS. Fauna of Tasmania Handbook No.3. University of Tasmania Press.

Drce, L.R., 1945: Measures of the amount of ecologic association between species. Ecology 26: 297-302.

Dixon, P., 1958: The structure and development of the thallus in the British species of Gelidium and Pterocladia. Ann. Bot. 22: 353-368.

Edgar, G.J., 1983a: The ecology of south-east Tasmanian phytal animal communities. 1. Spatial organization on a local scale. J. Exp. Mar. Biol. Ecol. 70: 129-157.

EDGAR, G.J., 1983b: The ecology of south-east Tasmanian phytal animal communities. II. Seasonal change in plant and animal populations. J. Exp. Mar. Biol. Ecol. 70: 159-179.

EDGAR, G.J., 1983c: The ecology of south-east Tasmanian phytal animal communities. III. Patterns of species diversity. J. Exp. Mar. Biol. Ecol. 70: 181-203.

EdgaR, G.J., 1984: General features of the ecology and biogeography of Tasmanian subtidal rocky shore communities. Pap. Proc. R. Soc. Tasm. 118: 173-186.

Faith, D.P., Minchin, P. \& Belbin, L., 1987 : Compositional dissimilarity as a robust measure of ecologica! distance. Vegetatio 69: 57-68.
FritsCH, F.E., 1935: THE STRUCTURE AND REPRODUCTION OF THE ALGAE, VOLUME I Cambridge University Press, Cambridge.

Fritsch, F.E., 1945: THE STRUCTURE AND REPRODUCTION OF THE ALGAE, VOLUME 2. Cambridge University Press, Cambridge.

Fuhrer, B., Christianson, I.G., Clayton, M.N. \& Allender, B.M., 1981: SEAWEEDS OF AUSTRALIA. A.H. \& A.W. Reed Pty Ltd, Sydney.

George, J.D. \& George, J.J., 1979: MARINE LIFE. AN ILLUSTRATED ENCYCLOPEDIA OF INVERTEBRATES IN THE SEA. Harrap, London.

GowER, J.C., 1966: Some distance propertics of latent root and vector methods used in multivariate analysis. Biometrika 53: 325-338.

Guller, E.R., 1952a: The intertidal ecology of the Eaglehawk Neck area. Pap. Proc. R. Soc. Tasm. 86: 13-29.

Gurler, E.R., 1952b: The marine algae of Tasmania: checklist with localities. Pap. Proc. R. Soc. Tasn. 86: $71-106$.

GulLer, E.R., 1954: The intertidal zonation at two places in southern Tasmania. Pap. Proc. R. Soc. Tasm. 88: $105-118$.

Guiler, E.R., Serventy, D.L. \& Willis, E.H., 1958: The Fisher Island Field Station - with an account of its principal fauna and flora. Pap, Proc. R. Soc. Tasm. 92: 165-183.

HALE, H.M., 1927: THE CRUSTACEANS OF SOUTH AUSTRALIA. PART I. Handbooks of the Flora and Fauna of South Australia. Government Printer, South Australia.

HALE, H.M, 1929: THE CRUSTACEANS OF SOUTH AUSTRALIA. PART II. Handbooks of the Flora and Fauna of South Australia. Government Printer, South Australia.

Johansen, H.W. \& Womersley, H.B.S., 1986: Haliptilon roseum (Corallinaceae, Rhodophyta) in southern Australia. Aust. J. Bot. 34: 551-567.

KAAS, P. \& VAN BELlE, R.A., 1980: CATALOGUE OF LIVING CHITONS (MOLLUSCA: POLYPLACOPHORA). Dr W. Backhuys Publ., Rotterdam.

KING, R.J., 1973: The distribution and zonation of intertidal organisms in Bass Strait. Proc. $R$. Soc. Vict. 85: $145-163$.

LEgendRE, L. \& LEgENDRE, P., 1983: NUMERICAL ECOLOGY. DEVELOPMENTS IN ENVIRONMENTAL MODELLING 3. Elsevier Scientific Publ. Co., New York.

Macpherson, J.H. \& Gabriel, C.J., 1962: MARINE MOLLUSCS OF VICTORIA. Melbourne University Press, Melbourne.

Marine Research Group of Victoria, 1984: COASTAL INVERTEBRATES OF VICTORIA. AN ATLAS OF SELECTED SPECIES. Harston, Partridge \& Co. Pty Ltd, Richmond, Victoria.

MAY, W.L. \& MACPHERSON, J.H., 1958: $A N$ ILLUSTRATED INDEX OF TASMANIAN SHELLS. Government Printer, Tasmania. 
Phillips, J.A., 1984: The validity of morphological and anatomical characters in distinguishing species of Ulva in southern Australia. In Irvine, D.E.G. \& John, D.M. (Eds): SYSTEMATICS OF THE GREEN ALGAE. Systematics Association Special Volume 27.

Ponder, W.F. \& Creese, R.G., 1980: A revision of the Australian species of Notoacmea, Collisella and Patelloida (Mollusca:Gastropoda:Acmaeidae). $J$. Malacol. Soc. Aust. 4: 167-208.

Rice, E.L., 1989: A statistical morphological analysis and taxonomic revision of the genus Xiphophora (Fucaceae). Bot. J. Linn. Soc. in press.

Rice Kenchington, E.L., 1987: Geographic, morphological and genetic variation in Xiphophore gladiata. Unpubl. Ph.D. thesis, Univ. Tasm.

Russell, G. \& VeltKamp, C.J., 1984: Epiphyte survival on skin-shedding macrophytes. Mar. Ecol. Prog. Ser. 18: 149-153.

SAEnger, P., 1974: Natural history of the Hogan Group 2. Some marine algae from Hogan Island, Bass Strait, with an account of the marine zonation. Pap. Proc. $R$. Soc. Tasm. 107: 73-81.

SaIto, Y. \& Womersley, H.B.S., 1974: The southern Australian species of Laurencia (Ceramiales: Rhodophyta). Aust. J. Bot. 22: 815-874.

Shepherd, S.A. \& ThOMAs, I.M., 1982: MARINE INVERTEBRATES OF SOUTHERN AUSTRALIA. PART I. Government Printer, South Australia.
SNEATH, P.H.A. \& Sokal, R.R., 1973: NUMERICAL TAXONOMY. Freeman, San Francisco.

SPSS INC., 1986: SPSS USER'S GUIDE. SECOND EDITION. McGraw-Hill Book Co., New York.

UNDERWOOD, A.J., 1981: Structure of a rocky intertidal community in New South Wales: Patterns of vertical distribution and seasonal changes. J. Exp. Mar. Biol. Ecol. 51: 57-85.

Westcott, G,, 1976: The intertidal crabs of Victoria Vict. Nat. 93: 237-245.

Womersley, H.B.S., 1964: The morphology and taxonomy of Cystophora and related genera (Phaeophyta). Aust. J. Bot. 12: 53-110.

WOMERSLEY, H.B.S., 1967: A critical survey of the marine algae of Southern Australia II. Phaeophyta. Aust. J. Bot. 15: 189-270.

WomersLeY, H.B.S., 1981: Marine ecology and zonation of temperate coasts. In Clayton, M.N. \& King, R.J. (Eds): MARINE BOTANY: AN AUSTRALIAN PERSPECTIVE. Longman Cheshire Pty Ltd, Melbourne.

WOMERSLEY, H.B.S., 1984: THE MARINE BENTHIC FLORA OF SOUTHERN AUSTRALIA. PART I. HANDBOOK OF THE FLORA AND FAUNA OF SOUTH AUSTRALIA. Government Printer, South Australia.

(accepted 12 May 1989) 